\title{
Cointegration of Stock Market and Exchange Rate in Indonesia
}

\section{Pribawa E. Pantas ${ }^{1 *}$, Muhamad Nafik Hadi Ryandono², Misbahul Munir ${ }^{3}$, Rofiul Wahyudi ${ }^{1}$}

${ }^{1}$ Faculty of Islamic Studies, Universitas Ahmad Dahlan (UAD) Yogyakarta

${ }^{2}$ Faculty of Economics and Business, Universitas Airlangga Surabaya

3Magister Ekonomi dan Keuangan Universitas Islam Indonesia, Yogyakarta

${ }^{1}$ Faculty of Islamic Studies, Universitas Ahmad Dahlan (UAD) Yogyakarta

*e-mail: pribawa.pantas@pbs.uad.ac.id

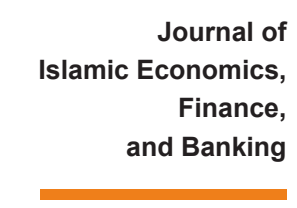

Vol. 2, No. 2, Desember 2019 , pp. 125-135, ISSN p:2622-4755 e:2622-4798

\begin{abstract}
This study aims to determine the long-term relationship between stock market and exchange rate in Indonesia. The research method used is Johansen cointegration test. The results of this study found no cointegration between the variables tested. Thus the exchange rate, JII, and IHSG have no relationship in the long term. The fluctuation of the rupiah exchange rate in recent years did not generally affect the performance of stock indices especially after the global financial crisis of 2008. This shows the capital market in Indonesia has a good performance so that it is not so sensitive to the sentiment of the decline in the rupiah against the US dollar. This finding is in line with the findings of Syahrer (2010) which states the exchange rate has no effect on the stock market.
\end{abstract}

Keywords: cointegration, exchange rate, JII, IHSG

\begin{abstract}
Abstrak
Penelitian ini bertujuan untuk mengetahui hubungan dalam jangka panjang antara pasar saham dan nilai tukar di Indonesia. Metode penelitian yang digunakan adalah uji kointegrasi Johansen. Hasil dari penelitian ini menemukan tidak ada kointegrasi antara variabel yang diuji. Dengan demikian nilai tukar, JII dan IHSG tidak mempunyai hubungan dalam jangka panjang. Adanya gejolak nilai tukar rupiah dalam beberapa tahun terakhir secara umum tidak mempengaruhi kinerja indeks saham terutama sesudah krisis keuangan global tahun 2008. Hal ini menunjukkan pasar modal di Indonesia mempunyai kinerja yang baik sehingga tidak begitu sensitif terhadap sentimen penurunan nilai tukar rupiah terhadap dolar Amerika Serikat. Temuan ini sejalan dengan temuan Syahrer (2010) yang menyatakan nilai tukar tidak berpengaruh pada pasar saham.
\end{abstract}

Kata Kunci: Kointegrasi, Nilai Tukar, JII, IHSG 


\section{INTRODUCTION}

The stock market began to be developed in Indonesia since 1972. IHTIFAZ - JIEFB In the development of Indonesia capital market has increased rapidly and become the target of investors both local investors and foreign investors (Moenir, 2015). However, further, development turned out that the Indonesian capital market experienced volatility (up and down movement). This can be seen in the mid to late 2008, the Composite Stock Price Index (IHSG) experienced a significant depreciation from the level of 2,165.94 to 1.8320.50. (WorldInvestment.com, 2016).

The same thing is experienced by the Islamic capital market in Indonesia. In this case, can see Jakarta Islamic Index (JII). In the middle of the end of $2008 \mathrm{JII}$ experienced a successive depreciation. Starting from the 430,291 level in June, then down to 387,8056 in July, down again at 356,095 in August, and continued to decline to 286,391 in September and the peak of depreciation was in October through 193,6829 (World Investments. com, 2016).

Depreciation on the stock market due to the infectious effects of the financial crisis originating from the United State or can also be called the Subprime Mortgage crisis. Subprime Mortgage is simply a condition of society that is not eligible to get housing loans because it had experienced a default in the previous period. This situation is a symptom of the global financial crisis in 2008 ago. The United States at that time applied a lot of housing loans but was not accompanied by fixed income and minimal savings also had a higher debt ratio compared to the income held (Moenir, 2015).

The implications of the US Financial Crisis have had a significant impact on the state of the global economy. Many of the countries whose economies have faltered because of the crisis, including Indonesia. The United States market is the third destination market of Indonesian exports after Japan and China. The United States as a major country that is also the destination market of Indonesia is experiencing the financial crisis, it will automatically affect the Indonesian economy (Moenir, 2015).

These conditions affect the stability of the Indonesian economy. One of the effects is the depreciation of rupiah exchange rate (exchange rate) against US dollar. Recorded in November 2008, the rupiah exchange rate against the US dollar depreciated at Rp 11,046.00 from the previous month, namely October Rp 9,913.00. (Bank Indonesia, 2016).

Changes in exchange rates both depreciation and appreciation will have an impact on import-export activities in the country concerned, as well as Indonesia and the United States. The decline in the rupiah against the US dollar (USD) will automatically affect the export of imports by both countries. In addition, USD is also the currency that dominates payments in the global market (Nezky, 2013).

The depreciating rupiah condition caused foreign investors to withdraw their funds from Indonesia resulting in a lack of foreign 
inflows in Indonesia. If the rupiah continues to depreciate, companies in Indonesia that use raw materials from imports also feel the consequences. Because if the rupiah depreciates the price of imported raw materials become expensive. This increases the burden of corporate spending and even if the company is not resilient to this condition will result in bankruptcy (Yuanisa, 2013).

This will lower the company's stock price and impact on the decline of JCI and JII. The decline in the exchange rate of the rupiah against foreign currencies (United States dollar) has an impact on the rising cost of importing raw materials and equipment required by companies for production purposes originating from abroad. Such circumstances lead to increased production costs of the company (Nugroho, 2008). That is, the weakening of the rupiah against foreign currencies (United States dollar) will negatively affect the Indonesian economy to lead to declining stock market performance, both the Conventional Stock Market (JCI) and Sharia Stock Market (JII) Indexed in Indonesia Stock Exchange (BEI).

After the period of financial crisis that occurred in the United States in 2008, the Indonesian stock market experienced a fairly good development. The condition of the global economy began to stabilize and provide a positive response to the existing capital markets in Indonesia.

In 2011 the US central bank (the Fed) issued a policy of giving an injection of stimulus funds or could be called Quantitative Easing (QE). $\mathrm{QE}$ is a policy with money printing programs and digging bonds as well as other financial assets from banks in the United States. This policy is intended to make money injections to banks in the United States with the aim of self-recovery pasca financial crisis of 2008 ago.

After the issuance of QE policy, foreign capital inflows flowed into Indonesia. Even the flow of foreign capital into Indonesia reached the greatest number in the history of the Indonesian capital market. In July 2011, the Jakarta Composite Index expanded to 4,130.80. Similarly with JII. In July 2011, JII progressed to a level of 567,119 (DuniaInvestasi. com, 2016).

The development of the stock market is also offset by the development of the rupiah against the US dollar. The rupiah against the US dollar appreciated. In the same period, in July 2011, the rupiah was at $8,465.00$ (Bank Indonesia, 2016). The recovering economic conditions of the United States from the financial crisis also triggered the Indonesian economy to be more stable. If Indonesia's economic condition stabilizes again then investors will be interested and invest in Indonesia stock market. This makes the stock market index rise and market sentiment move in a positive direction in response to policies issued by the United States government by providing QE stimulus.

On December 19, 2013, the Fed declared to withdraw the QE stimulus. The Fed issued a new policy will pull the QE stimulus gradually 
starting in January 2014. In this policy, the Fed will reduce its stimulus fund of USD 10 billion.

IHTIFAZ - JIEFB

This policy again destabilized the global economy and its impact on the Indonesian economy. This can be seen in the movement of the rupiah exchange rate that has increased continuously. In December 2013, the rupiah depreciated again at Rp 12,189.00. Depreciation of the rupiah continues to occur until January 2014 reached Rp 12.226,00.

However, the weakening of the rupiah exchange rate due to the policy of withdrawal of QE by the Fed has no significant effect on the condition of the Indonesian capital market. This can be seen from the movement of IHSG and JII which tend to be stable. Even when the rupiah depreciated in December 2013, the JCI was seen rising at $4,274.17$ and in January 2014 it was up at $4,418.75$ points. Similarly with JII. In December 2013, JII was at 585.11 and then increased in January 2014 was at 602,873 points (World Investment, 2016, Bank Indonesia, 2016).

Withdrawal of QE stimulus funds made by the Fed caused the economy of Indonesia experiencing sluggishness. The lethargy of Indonesia's economy is seen until the end of 2014 where the rupiah exchange rate is still depreciated. In September 2014, the rupiah exchange rate was at $\mathrm{Rp} 12,212.00$ and continued to depreciate to $\mathrm{Rp}$ 12,440.00 in December 2014 (Bank Indonesia, 2016).

Table 1. JCI, JII and Rupiah Exchange Rate Movements against the United States 2006 - 2016

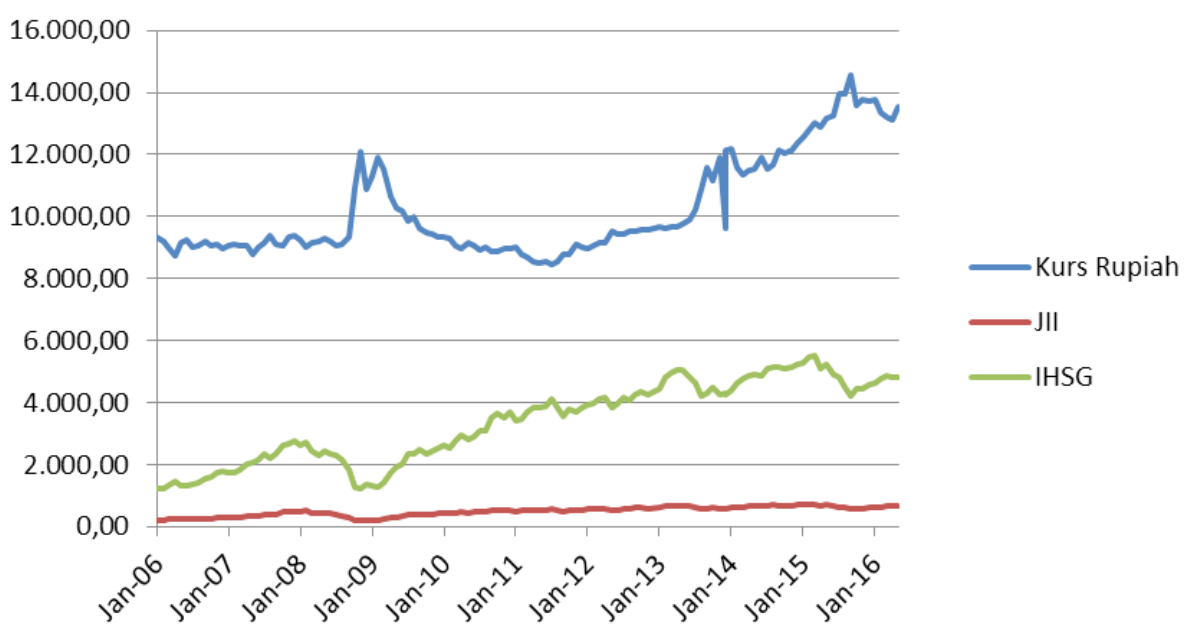

Source: Bank Indonesia (2016) and WorldInvestment.com (2016)

If the rupiah exchange rate continues to depreciate, it causes a massive withdrawal of funds by foreign investors. The finance ministry reported that by 2014 the value of withdrawals by foreign investors reached 10.09 trillion or 801 million US dollars from the obligor market. 
One of the causes of the massive withdrawal of foreign funds is due to speculation of a rise in US benchmark interest rate. These conditions make the demand for emerging-market assets will be eroded (Moenir, 2015).

The rupiah exchange rate depreciated during 2014, but not the case with the Indonesian capital market. This can be seen from the movement of JCI and JII which even increased slowly and increased with certainty. In January 2014, the JCI was at 4,418.75 points. Then at the end of 2014, ie in December has increased that is at the level of 5226.94 points. The same thing happened to JII, in January $2014 \mathrm{JII}$ was at the level of 602,873 points. While in December 2014, JII has increased to the level of 691,039 points (DuniaInvestasi.com).

This phenomenon is interesting where the movement of the rupiah exchange rate is contrary to the movement of stock prices. The rupiah depreciated but the stock price index increased. This fact contradicts some previous research findings which suggest that the movement of the rupiah exchange rate significantly affects the stock price index (JCI and JII).

The research ever conducted by Nurrohim (2013) using Granger Causality causality test concludes that between exchange rate and JCI there is one-way causality relationship that is rupiah exchange rate influence JCI. While Sowwam (2005) examined the relationship of the exchange rate and JCI using Granger causality test showed that there was a bidirectional relationship between IHSG and rupiah exchange rate with confidence level reached 90 percent.

Based on the above explanation, there is a disparity between the results of previous studies with existing phenomena in the field. So this research is done to re-confirm how the relationship between the exchange rate and stock market as well as to re-verify the differences of previous research with the phenomena that occur in the field.

\section{LITERATURE REVIEW}

\section{Exchange Rate}

The exchange rate is the price of a country's currency against another country or the currency of a country is expressed in the currency of another country. An increase in the exchange rate is called the depreciation (decline in the value of the currency) in the country against foreign currencies. While the decline in the exchange rate is called the appreciation, namely the increase in the exchange rate of domestic currency against foreign currencies. (Khasanah, 2016).

Mankiw (2006) discloses the exchange rate between the two countries is the price level agreed by the people of both countries to transact in trading activities. If the weakening exchange rate is called depreciation. Depreciation is the decline in the exchange rate of 
domestic currency against the value of foreign currency. Meanwhile, if the exchange rate strengthened is called the appreciation. Appreciation IHTIFAZ - JIEFB is the rise in the exchange rate of domestic currency against foreign currency. In theory in general, the exchange rate is determined by the intersection of the market demand curve and the market supply curve.

\section{Composite Stock Price Index (ISHG)}

According to Nurazi et al (2013) The Composite Stock Price Index, hereinafter abbreviated as JCI, is one of the stock market indices used by Indonesia Stock Exchange (IDX) which was formerly called Jakarta Stock Exchange (BEJ). This index was first introduced on April 1, 1983, as an indicator of stock price movements on the JSE. This index includes price movements of all ordinary shares and preferred stocks listed on the IDX. The Basic Day for JCI computation is August 10, 1982. On that date, the Index is assigned with Basic Value 100 and the listed shares at that time amounted to 13 shares.

\section{Jakarta Islamic Index (JII)}

Manurut Fauzi (2016) JII (Jakarta Islamic Index) is one of the stock indices in Indonesia that calculates the stock price index for the type of stocks that meet the criteria of sharia. JII is formed from cooperation between PT. Jakarta Stock Exchange with PT. Danareksa Investment Management (PT DIM). JII was developed since July 3, 2000, and every period of the shares included in the JII index amounted to 20 shares. JII uses the base day of January 1,1995, with a base value of 100 .

Many researchers are conducting research on themes related to the relationship between exchange rates and stock market sectors. Aurangzeb (2012) entitled "Contributions of Banking Sector in Economic Growth: A Case of Pakistan" using Augmented Dickey-Fuller (ADF) analysis tool. The result of this research is a two-way causal relationship between the banking sector and economic growth indicator.

Nugroho (2009) under the title "Analysis of Causality Relationship between Macro-Economic Variables with Sharia Stock Price in JII period July 2002 to June 2007". Analyzer used is VAR. The results of this study indicate a one-way causality relationship between macroeconomic variables with JII, where JII is influenced by macroeconomic variables.

Maharani (2005) entitled "The Relationship of Causality between Macro-Economic Variables and Sharia Stock Price in JII Period from January 2001 to May 2005" by using Error Correction Model (ECM) analysis tool. The result of this research is there is no causal relationship between JII and some macroeconomic variables such as interest rate and rupiah exchange rate.

Research conducted by Syahrer (2010) entitled "The Linkage of Rupiah Exchange Rate to Stock Price Index in Indonesia Stock Exchange (BEI)". Analyzer used in this research is VAR. The results of this study 
do not have a direct impact on the movement of exchange rates on the movement of stock prices.

Novianto (2011) entitled "Analysis of the Effect of Rupiah Exchange Rate on US Dollar, Interest Rate of SBI, Inflation and Money Supply on JCI in IDX from January 1999 to June 2006". Analyzer used is multiple

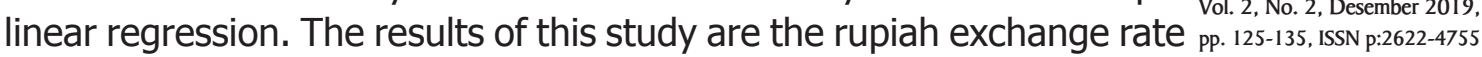
and interest rates have a negative influence on JCI. While inflation and money supply have a positive relationship to JCI.

There are several similarities and differences between this study and previous studies. The equation lies in the object of research and analysis tool. While the difference is located on the vulnerable time of research data. In this study, the object of research that is used is the exchange rate of rupiah, JCI, and JII. While vulnerable time data used is started from January 2006 until May 2016. The analysis tool used is using Johansen cointegration test.

\section{METHODOLOGY}

This research uses quantitative descriptive approach. Data from the variables used in this study were processed using the help of statistical analysis tools. The type of data used is secondary data obtained from relevant agencies that provide research data. Data were identified to explain the underlying phenomenon of the study.

\section{SAMPLE RESEARCH}

This study was conducted to test the long-term relationship between stock market and exchange rate in Indonesia. In order to explain the object of research, the variables used in the research are the rupiah exchange rate against the US dollar in terms of exchange rate, then the Composite Stock Price Index (IHSG) and Jakarta Islamic Index (JII) from the stock market side. The data used in this study is time series data, in the form of monthly data of rupiah exchange rate, JCI and JII period January 2006 to May 2016.

\section{MODEL ANALISIS DATA}

\section{Unit Root Test}

According to Nurazi et al (2013) in the model econometric time series data is tested must be stationary. An estimate would yield a meaningless conclusion if the data used contained the root of the unit (not stationary). Non-stationary data can result in the spurious regression in the regression estimation results. This can be seen in the high coefficient of determination R2 and the value of $t$ statistic not significant. The existence of spurious regression results will lead to incorrect interpretation results. The time series data type is said to be stationary if the mean, variant, covariant on each lag is kept the 
same at all times (Widarjono, 2009). Here are the formulations in the stationary test data:

$$
\Delta Y_{t}=a_{0}+y Y t_{-1}+\beta_{i} \sum_{t}^{p}=\Delta Y_{t-i+1} \varepsilon_{t}
$$

$$
\begin{array}{ll}
\Delta Y_{t} & =\text { The shape of the firs difference } \\
a_{0} & =\text { Intercept } \\
Y & =\text { Variables tested stationarity } \\
P & =\text { The length of the lag used in the model } \\
\varepsilon & =\text { Error Term }
\end{array}
$$

\section{Cointegration Test}

Johansen method is one approach that can be used in conducting cointegration test (Widarjono, 2009). The cointegration test using Johansen method can be analyzed through the Autoregressive model with $\mathrm{P}$ order which can be described by the following equation:

$$
y_{t}=A_{i} y_{t-1}+\ldots+A_{i} y_{t-p} I+B \pi_{t}+\varepsilon_{t}
$$

$y_{t}=$ The $\mathrm{k}$-vector in the variable is not stationary

$\pi_{t}=$ The d-vector of the deterministic variable

$\varepsilon_{t}=$ Innovation Vector

\section{RESULTS AND DISCUSSION}

\section{Unit Root Test}

Nurazi et al. (2013) revealed unit root test needs to be done to see data behavior. The data being tested must be known in advance whether the data is stationary or not stationary. If the data is not stationary or non-stationary, then the data must be differentiated. Unit root testing is generally done by running ADF and DF functions. Based on unit root test results using Augmented Dickey-Fuller (ADF) and Dickey-Fuller (DF) of the variables analyzed in this study, stationary data after being deferred at first order or stationary at differents first level. The test is done at a none. The following results from the unit root test of exchange rate variables, JII and IHSG:

Table 2. Unit Root Test Results

\begin{tabular}{lrr}
\hline \multicolumn{1}{c}{ Variabel } & \multicolumn{1}{c}{ Level } & First dif \\
\hline LNJII & -2.733671 & -8.63811 \\
Prob & 0.2252 & 0.0000 \\
Lnkurs & -1.629321 & -10.2212 \\
Prob & 0.7758 & 0.0000 \\
Lnihsg & -2.475787 & -8.4935 \\
Prob. & 0.3396 & 0.0000 \\
\hline
\end{tabular}


Based on the above table, all variables are not stationary at the level. This can be seen from the probability value of all the variables tested greater than the value of $t$ statistics. Then tested at the next

level is at different first level. After the test is done at different first level then stationary data at different first level. This can be seen from the probability value of all tested variables smaller than the value of Vol. 2, No. 2, Desember 2019 , t statistics. One such example is the JII variable at the level of its probability 0.0000 which is smaller than its statistical t value of 8.63811 .

\section{Cointegration Test}

Cointegration test was conducted to determine the possibility of a long-run relationship between the observed variables (Nurazi et al, 2013). Cointegration test in this study using Johansen approach and obtained the results of the analysis as follows:

Table 3. JJ Cointegration Test Results

\begin{tabular}{lcrrr}
\hline Hypothesized & Trace & \multicolumn{1}{c}{$\mathbf{0 . 0 5}$} & Max-Eigen & \multicolumn{1}{c}{$\mathbf{0 . 0 5}$} \\
\hline No. of CE(s) & Statistic & Critical Value & Statistic & Critical Value \\
None & 35.43031 & 42.91525 & 20.60745 & 25.82321 \\
At most 1 & 14.82286 & 25.87211 & 11.76051 & 19.38704 \\
At most 2 & 3.062355 & 12.51798 & 3.062355 & 12.51798 \\
\hline
\end{tabular}

Based on the cointegration test results table above, it can be seen that there is no cointegration between the variables tested. This can be seen from the trace value of the statistic is smaller than the value of trace critical value. Thus, all the variables tested in this research are exchange rate, JII and IHSG have no long-term relationship influence.

These findings reveal several things. Firstly, the fluctuation of the rupiah exchange rate that has declined in recent years generally does not affect the performance of stock indexes in the capital market especially during and after the global financial crisis of 2008. This shows that the capital market in Indonesia has a good performance so not so sensitive to the sentiment for the decline in the rupiah against the US dollar. This finding is in line with the findings of Syahrer (2010) which shows that the exchange rate has no effect on the stock market.

Second, JCI and JII movements do not affect each other. This means that if there is a shake in the movement of JCI, it will not affect JII and vice versa. This indicates that in general, the two indexes have a good performance so that they are not affected by each other during and after the global financial crisis of 2008. This finding is in line with the results of research conducted by Karim and Kassim (2010) which shows no effect between sharia share markets before and during the 2008 global financial crisis in five countries (Indonesia, Malaysia, Japan, the United Kingdom and the United States). From these findings also recommend multiplying the diversification of portfolios in the stock market. 


\section{CONCLUSION AND RECOMMENDATION}

The aim of this research is to know cointegration between rupiah IHTIFAZ - JIEFB exchange rate, JCI and JII period January 2006 to May 2016. The result of this research shows that there is no cointegration between the variables tested. This shows that exchange rates, JII and JCI have no long-term relationship influence.

These findings reveal several things. Firstly, the fluctuation of the rupiah exchange rate that has declined in recent years generally does not affect the performance of stock indexes in the capital market especially during and after the global financial crisis of 2008. This shows that the capital market in Indonesia has a good performance so not so sensitive to the sentiment for the decline in the rupiah against the US dollar. This finding is in line with the findings of Syahrer (2010) which shows that the exchange rate has no effect on the stock market.

Second, JCI and JII movements do not affect each other. This means that if there is a shake in the movement of JCI, it will not affect JII and vice versa. This indicates that in general, the two indexes have a good performance so that they are not affected by each other during and after the global financial crisis of 2008. This finding is in line with the results of research conducted by Karim and Kassim (2010) which shows no effect between sharia share markets before and during the 2008 global financial crisis in five countries (Indonesia, Malaysia, Japan, the United Kingdom and the United States). From these findings also recommend multiplying the diversification of portfolios in the stock market.

\section{REFERENCE}

Aurangzeb. (2010). "Contributions of Banking Sector in Economic Growth: a Case of Pakistan". Economics and Finance Review vol. 2(6) pp. 45 - 54, August, 2012.

Bank Indonesia: http//: www.BI.go.id, data nilai tukar rupiah.

Duniainvestasi.com, data IHSG dan JII.

Fauzi, Ahmad Syahrul. (2016). "Analisis Pengaruh Variabel Makroekonomi Terhadap Stabilitas Perusahaan yang Terdapat di Jakarta Islamic Index Periode 2010-2014". Fakultas Ekonomi dan Bisnis Islam, Universitas Islam Negeri Sunan Kalijaga Yogyakarta.

Karin, Bakri Abdul dan Kassim, Nor Akila Mohd. 2010. "The us subprime crisis and islamic stock markets integration ", Proceedings of International Islamic Finance Conference 2010.

Khasanah, Eka Siti. (2016). "Pengaruh Volatilitas Nilai Tukar Terhadap Ekspor Indonesia ke Tiga Negara Mitra Ekspor Utama (Periode 2000:1-2014:4.". Fakultas Ekonomi dan Bisnis Islam, Universitas Islam Negeri Sunan Kalijaga Yogyakarta. 
Maharany, Reny. (2005). "Hubungan Kausalitan antara Variabel Makro dan Harga Saham Syariah di Jakarta Islamic Indeks (JII) Periode Januari 2001-Mei 2005". Program Pasca Sarjana UI.

Mankiw, N. Gregory, 2006. Pengantar Ekonomi Makro. Ghalia Indonesia. Jakarta. Moenir, Marseilla Meitalia. (2015). "Hubungan Kausalitas Antara Kurs pp. 125-135, ISSN p:2622-4755 Rupiah Terhadap Dolar Amerika Serikat dengan Indeks Harga Saham Gabungan Periode Januari 2009-Desember 2014". Universitas Brawijaya.

Novanto, Aditya. (2011). "Analisis Pengaruh Nilai Tukar (kurs) Dolar Amerika/Rupiah (US\$/Rp), Tingkat Suku Bunga SBI, Inflasi dan Jumlah Uang Beredar (M2) Terhadap Indeks Harga Saham Gabungan (IHSG) di Bursa Efek Indonesia (BEI) Periode 1999.1 2010.6". Undip.

Nugroho. (2008). "Evaluasi Terhadap Faktor-Faktor Yang Mempengaruhi Investasi Di Indonesia Dan Implikasi Kebijakannya". Jurnal Riptek, Vol.2, No.1. Fakultas Ekonomi Universitas Diponegoro Semarang.

Nugroho, Faeshol Cahyo. (2009). "Analisis Hubungan Kausalitas Antara Variabel Makro Ekonomi dengan Harga Saham Syariah pada Jakarta Islamic Indeks (JII) Juli 2002 - Juni 2007". UGM.

Nurazi dkk. 2013. "Analisis Hubungan Kointegrasi dan Kausalitas Serta Hubungan Dinamis Antara Shanghai Composite Index (SHCOMP) China dan Indeks Harga Saham Gabungan (IHSG) Indonesia", Program Studi Manajemen Fakultas Ekonomi Universitas Bengkulu: Laporan Penelitian Hibah.

Sowwam, Muhammad. (2005). "Analisa Hubungan Antara Nilai Tukar Dengan Indeks Harga Saham Gabungan Di Indonesia". Simposium Riset Ekonomi II. Surabaya.

Syahrer, Venny. (2009). Keterkaitan Nilai Tukar Rupiah Dengan Indeks Saham di Bursa Efek Indonesia (BEI)". IPB.

Widarjono, A. (2009). Ekonometrika Pengantar dan Aplikasinya, Yogyakarta: Ekonisia Fakultas Ekonomi UII.

Yuanisa, Tisa. (2013). "Analisis Pengaruh BI Rate, Kurs, Inflasi, Indeks Dow Jones dan Indeks Nikkei 225 Terhadap Indeks Harga Saham Gabungan (IHSG) di BEI Periode 2006.1 - 2012.12". Undip. 